\title{
Flysjun í slagæoum á hálsi - yfirlitsgrein
}

\section{Ólafur Árni \\ Sveinsson ${ }^{1}$ \\ sérfræðingur í \\ taugasjúkdómum}

Ólafur Kjartansson ${ }^{2}$

sérfræðingur í myndgreiningu

Einar Már

Valdimarsson ${ }^{3}$

sérfræðingur í

taugasjúkdómum

Lykilorð: flysjun í hálsæðum, innri hálsslagæð, hryggslagæð, heilablóðpurrð, heiladrep.

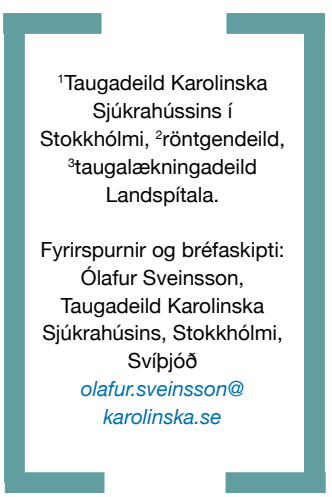

\section{Ágrip}

Áður var flysjun í innri hálsslagæð (arteria carotis interna) eða hryggslagæð (arteria vertebralis) talin sjaldgæf ástæða heilablóðfalls en vegna betri greiningartækni og aukinnar vitneskju lækna um sjúkdóminn greinist flysjun mun oftar en áður. Er flysjun nú talin ein helsta ástæða heilablóðpurrðar hjá yngri og miðaldra einstaklingum. Meingerð flysjunar er lítt pekkt. Líklega er oftast um að ræða undirliggjandi galla í æðarvegg ásamt útleysandi páttum eins og áverkum á hálsi eða sýkingu. Grunur um sjúkdóminn vaknar við klínísk einkenni á borð við skyndilegan verk á hálsi, andliti eða höfði og/eða Horners-heilkenni með eða án einkenna heilablóðpurrðar. Greiningin er staðfest með pví að sýna fram á dæmigerðar breytingar á æðinni með myndrannsókn. Hefðbundin meðferð hefst með heparín-innrennsli í æð eða lágmólekúlarheparíni gefið undir húð. Síðan tekur við blóðpynning með warfaríntöflum (með pað að markmiði að halda INR milli 2,0-3,0) í 3-6 mánuði.

\section{Inngangur}

Flysjun í innri hálsslagæð (arteria carotis interna) eða hryggslagæð (arteria vertebralis) hefst með rofi á innra borði slagæðarinnar, blóð prengir sér milli innsta lags (tunica intima) og miðlags (tunica media) eða milli miðlags og ysta lags (subadventitial) (mynd 1). Ef blæðing verður milli innsta lags og miðlags æðar veldur hún prengingu eða lokun á eiginlegu holrúmi æðar og myndar falskt holrúm. Ef blæðing nær út fyrir miðlag getur pað leitt til víkkunar á ytra borði æðarinnar og myndun falsks æðagúlps (pseudoaneurysma). Prenging eða lokun á hinu eiginlega holrúmi æðarinnar getur truflað blóðflæði til heilans, auk pess sem blóðflæðið getur orðið iðukennt (turbulent) og forsendur skapast til segamyndunar- og reks til heilans sem leitt getur til heiladreps.

Lengi var flysjun talin sjaldgæf ástæða heilablóðfalls. Með tilkomu fljótvirkrar og hættulítillar tækni við myndrannsóknir á æðum og aukinnar vitneskju um sjúkdóminn, er flysjun nú talin ein helsta ástæða heilablóðpurrðar og heiladreps hjá yngri og miðaldra einstaklingum (undir 50 ára aldri). Flysjun er talin valda $10-25 \%$ heiladrepa í pessum aldurshópi, næst á eftir segareki frá

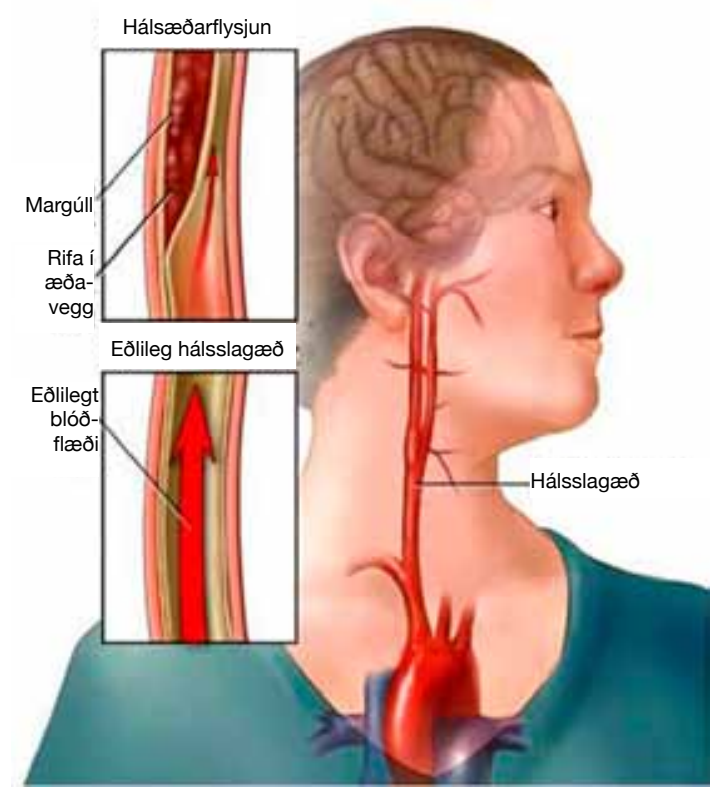

Mynd 1. Flysjun í hálsslagæð, blóð sést á milli laga og myndar margúl í æðarveggnum.

Birt meơ leufi Mayo Foundation for Medical Education and Research, öll réttindi áskilin.

hjarta. ${ }^{1,2}$ Pví er mikilvægt að hafa flysjun í huga hjá yngri og miðaldra sjúklingum með heilaslag. Í pessari grein er lögð áhersla á flysjun hálsslagæða utan höfuðkúpu (extra cranial).

\section{Faraldsfræði}

Nýgengi flysjunar í innri hálsslagæð er um 1-3 tilfelli á hverja 100.000 íbúa á ári eftir rannsóknum. ${ }^{3,4}$ Рað jafngildir fjórum til níu tilfellum árlega á Íslandi. Í nýlegri stórri finnskri rannsókn par sem 301 sjúklingur tóku pátt, reyndist nýgengi flysjana í hálsslagæðum (bæði innri hálsslagæð og hryggslagæð) vera heldur lægra en í heimildum 3 og 4 eða 1,43/100.000/ár. ${ }^{5}$ Í rannsókninni var skipting flysjana á pann veg að 52\% höfðu flysjun í innri hálsslagæð og 48\% í hryggslagæð. Í ofannefndri rannsókn reyndust flysjanir í slagæðum á hálsi algengari hjá körlum (68\%). ${ }^{5}$ Um $70 \%$ peirra sem greinast með flysjun eru á aldrinum 35-50 ára. Pó parf að hafa í huga að sjaldnar er leitað að flysjun hjá eldra fólki. Ekkert er vitað um tíðni einkennalausra flysjana. 
Tafla I. Sjúkdómar sem tengjast aukinni áhættu á flysjun i slagæđum á hálsi.

\begin{tabular}{l}
\hline Bandvefs- og vöðvamisvöxtur \\
\hline Marfan-heilkenni \\
\hline Ehlers-Danlos-heilkenni \\
\hline Erfðaríkjandi blöðrunýru \\
\hline Beinstökkvi \\
\hline Alpha-1-antitrypsin-skortur \\
\hline Gerð 1 kollagenstökkbreyting \\
\hline Aðrir bandvefssjúkdómar \\
\hline
\end{tabular}

\section{Áhættupættir}

Innri áhættupættir

Í rannsóknum á einstaklingum með flysjun er tíðni æðakölkunar lág. Pað bendir til pess að hefðbundnir áhættupættir fyrir heilablóðfalli séu ekki að verki. ${ }^{5,6}$ Pó virtust reykingar vera áhættupáttur í finnsku rannsókninni. ${ }^{5}$

Sjúkleiki í æðaveggnum, til að mynda arfgengir bandvefssjúkdómar eða sjúkdómar par sem galli er í kollagen- eða elastínvef, geta legið til grundvallar hjá allt að einum priðja hluta sjúklinga (sjá töflu I). ${ }^{1,7-9}$ Aukinni áhættu á flysjun hefur til að mynda verið lýst hjá einstaklingum með bandvefs- og vöðvamisvöxt, Ehlers-Danlos-heilkenni, Marfans-heilkenni, erfðaríkjandi blöðrunýru og beinstökkva., ${ }^{7}$ Til eru dæmi um flysjanir hjá nokkrum einstaklingum í sömu fjölskyldu sem benda til ættlægs páttar. Pau tilfelli eru pó sjaldgæf.

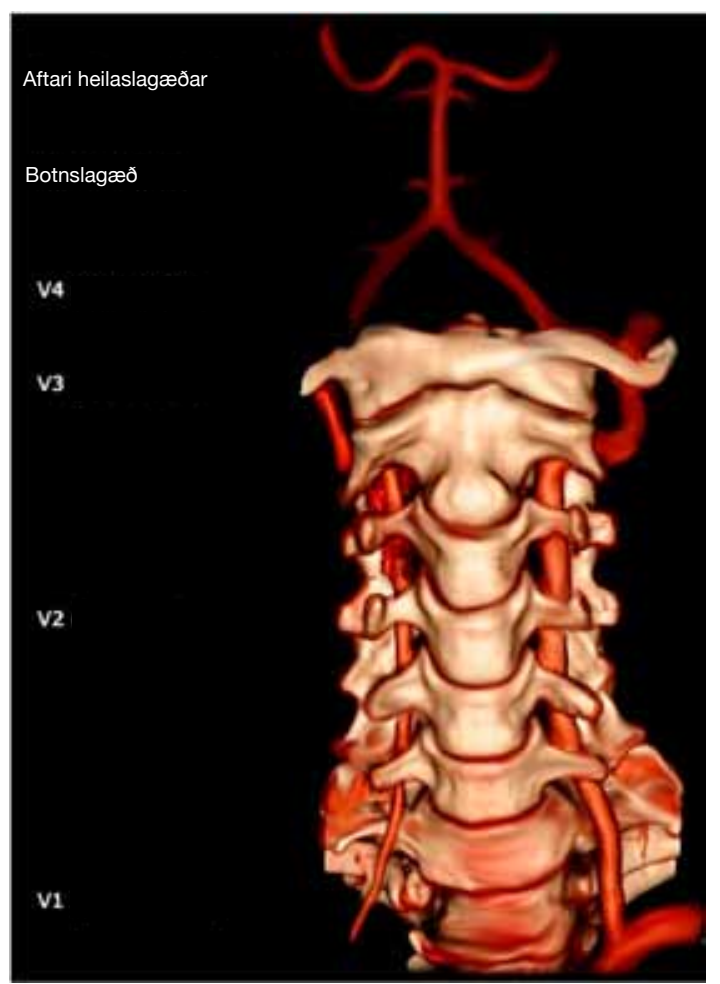

Húðsýni frá einstaklingum með hálsslagæðarflysjun hafa sýnt breytingar sem benda til undirliggjandi bandvefssjúkdóms án pess að hægt hafi verið að skilgreina pað nánar. ${ }^{10}$ Rannsókn byggð á ómskoðun á innri hálsslagæð sýndi að breytingar á pvermáli æðarinnar í takt við hjartslátt (cardiac cycle) voru marktækt meiri hjá einstaklingum með flysjun borið saman við viðmiðunarhóp. Pessar niðurstöður gefa til kynna að galli í utanfrumuefninu (extracellular matrix) geti átt hlut að máli, að minnsta kosti hjá sumum. Eigi að síður hafa víðtækar erfðarannsóknir sem beinst hafa að stökkbreytingum í utanfrumuefninu ekki borið árangur. ${ }^{9}$

Fundist hafa vísbendingar um að hækkun á hómócysteiniíblóðigeti tengst flysjun. ${ }^{11-14}$ Ísumum rannsóknum virðist mígreni vera áhættupáttur., ${ }^{5,15}$ ${ }^{16}$ Nokkrar rannsóknir hafa sýnt fram á tengsl mígrenis og virkni elastasa í blóði sem vekur spurningar um sameiginlegan undirliggjandi orsakapátt fyrir mígreni og hálsslagæðarflysjun. ${ }^{17}$ Í 7-15\% tilvika greinist flysjun í fleiri en einni æð. ${ }^{5,18}$ Líklegt er að sá sjúklingahópur hafi undirliggjandi galla í æðaveggjum.

\section{Ytri áhættupættir}

Ljóst pykir að í vissum tilfellum verður flysjunin í kjölfar áverka. Stundum er um öflugan áverka á háls að ræða par sem sambandið pykir augljóst. Flysjana verður einnig vart í kjölfar vægari áverka eins og að bera punga tösku, minni háttar ípróttaslysa og jafnvel eðlilegra athafna daglegs lífs, svo sem að hnerra eða hósta, en við pær aðstæður er orsakasambandið óvissara. ${ }^{19-22}$ Vægi áverka î meingerð flysjunar er pví oft óljóst.

Tengsl milli hálshnykkingar í meðferðarskyni og hálsæðaflysjunar, sérstaklega hryggslagæðaflysjunar, hafa lengi verið til umræðu. Telja menn sig hafa sterk rök fyrir pví að hnykking geti leitt til flysjunar. ${ }^{23-25}$ Nálægð hryggslagæðarinnar við pvertinda $\mathrm{C} 1$ og C2 liðbolanna getur hugsanlega átt pátt í meingerðinni. Svokallaðir V1 og V3 hlutar hryggslagæðarinnar eru hreyfanlegastir gagnvart aðliggjandi beini og getur pað hugsanlega skýrt af hverju flysjun er algengust í V3 hluta æðanna (sjá mynd 2). ${ }^{26}$

Nýleg sýking, sérstaklega í öndunarfærum, virðist vera áhættupáttur fyrir hálsslagæðarflysjun. ${ }^{5,27,28}$ Tilgátan er sú að sýkingin hafi í för með sér tímabundnar bólgubreytingar í æðunum. petta er enn frekar stutt með árstíðabundnum breytileika ítíðni hálsslagæðarflysjunar (algengust á haustin). ${ }^{29}$ Allt eins gæti verið um áverka á æðina að ræða vegna hósta og hnerra.

Flysjun í slagæðum á hálsi er sennilega í 
mörgum tilfellum vegna samverkandi áhrifa undirliggjandi galla í æðarvegg og ytri áhættupátta. $^{11}$

\section{Klínísk einkenni}

Hálsslagæðarflysjun (carotid artery dissection) Algengasta einkennið er verkur í hálsi eða höfði. Verkurinn er venjulega kröftugur, kemur snemma í sjúkdómsferlinu og er staðsettur kringum augað, á gagnaugasvæðinu og/eða hliðlægt á hálsi sömu megin og flysjunin. ${ }^{30,31}$ Honum getur fylgt púlserandi hljóð sömu megin. ${ }^{31}$ Verkurinn getur komið skyndilega og verið pað slæmur að grunur vaknar um innanskúmsblæðingu (subarachnoid hemorrhage).

Horners-heilkenni kemur fyrir í um helmingi tilfella (mynd 3). Раð er vegna prýstingsáhrifa á sympatísku taugapræðina sem umlykja innri hálsslagæðina. Oft er aðeins hluti af teiknum Horners til staðar. ${ }^{21}$ Horners-heilkenni ásamt skyndilegum verk í höfði og/eða hálsi sömu megin, á pví að vekja sterkan grun um flysjun í innri hálsslagæð. Hafa ber í huga að flysjun î innri hálsslagæð getur gefið einkenni frá neðri heilataugum. Er hér átt við taugar eins og $\mathrm{N}$. hypoglossus og N. Vagus með tilheyrandi einkennum frá munnholi og tungu. Ástæðan fyrir pessu er óviss en prýstingur á smáæðarnar sem næra taugarnar eða beinn prýstingur á taug vegna blæðingarinnar í æðarveggnum eru mögulegar skýringar. Pegar einkenni eru frá neðri heilataugum veldur pað oft vanda við greiningu par sem sjónir beinast að heilastofnsáfalli frekar en flysjun.

Tíðni heilablóðpurrðar við flysjun í innri hálsslagæð er ekki fyllilega pekkt en rannsóknir benda pó til að heiladrep eigi sér stað í um pað bil $60-70 \%$ tilfella. ${ }^{5}$ Heiladrep verða oftast á næringarsvæði miðhjarnaslagæðarinnar (a. cerebri media) og eru talin verða á allra fyrstu dögunum eftir flysjunina. ${ }^{5}$ Blóðpurrðareinkenni vikum/ mánuðum eftir flysjun eru talin afar sjaldgæf. ${ }^{32}$

Blóðpurrðareinkenni án annarra einkenna geta komið fyrir en oftar er verkur og/eða Hornersheilkenni fyrirboði.

Hryggslagæðarflysjun (vertebral artery dissection) Algengustu einkennin eru verkur í hnakka eða aftarlega í höfði. ${ }^{33}$ Yfirleitt er verkurinn verri peim megin sem flysjunin er. Oft er verknum ekki lýst sem sérstaklega slæmum eða af óvenjulegri gerð, sem getur gert greininguna erfiða.

Algeng einkenni frá aftari blóðveitu eru svimi, sjóntruflanir, kyngingarörðugleikar og jafnvægistruflun. Algengt er svokallað Wallenbergs-

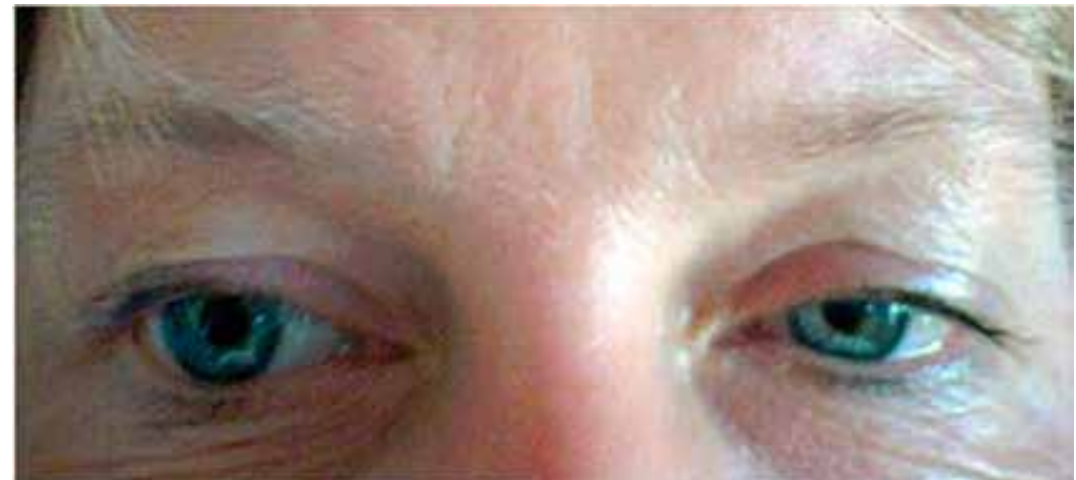

heilkenni (lateral medullary syndrome) í heild eða að hluta til. Раð samanstendur af Hornersheilkenni, skyntruflun í andliti og slingri (ataxia) útlima sömu megin, ásamt minnkuðu skyni fyrir sársauka og hita í útlimum gagnstæðrar hliðar. Önnur einkenni hryggslagæðarflysjunar geta verið blóðpurrðareinkenni frá litla heila, stúku (thalamus), brú (pons) eða aftari heilaslagæð (posterior cerebral artery. ${ }^{33}$

Athyglisvert er að Horners-heilkenni getur sést bæði við flysjun í innri hálsslagæð og hryggslagæð. Við flysjun í innri hálsslagæð verður áverki á sympatíska taugapræði sem umlykja æðina. Við flysjun í hryggslagæð orsakast heilkennið af blóðpurrð hliðlægt í mænukylfu.

Blóðpurrðareinkenna verður vart hjá 80-90\% sjúklinga sem greinast með hryggslagæðarflysjun ${ }^{5}$, ${ }^{18}$ og eru pau pví heldur algengari en hjá sjúklingum sem greinast með flysjun í innri hálsslagæð. ${ }^{5,21,}$ ${ }^{26}$ Hins vegar hafa heiladrepin á næringarsvæði fremri blóðveitu almennt alvarlegri afleiðingar í för með sér en pau sem verða á svæði aftari blóðveitu. $^{5}$

Ávallt er rétt að hafa flysjun í huga hjá einstaklingum með skyndilegan verk í hálsi, hnakka eða höfði, samfara taugabrottfallseinkennum og/eða Horners-heilkenni.

\section{Myndrannsóknir}

Flysjun í slagæð verður vegna pess að farvegur opnast fyrir slagæðablóð inn í æðavegg. Blæðing inn 1 æðavegg verður oftast á milli innsta lags og miðlags en blóðið getur einnig rofið miðlag og legið milli miðlags og ysta lags. Ef blóð kemst milli innsta lags og miðlags æðar veldur fyrirferðin prengingu eða lokun á eiginlegu holrúmi æðarinnar og einnig getur falskt holrúm samsíða pví eiginlega myndast. Ef blæðing nær út fyrir miðlag getur pað leitt til víkkunar á ytra borði æðarinnar og myndunar falsks æðagúlps.

Flysjun getur sést við myndgreiningu sem margúll (hematoma) í æðarvegg, tvö holrúm, staðbundin prenging eða lokun á eiginlegu hol-
Mynd 3. Ptosis og miosis vinstra megin, sem er hluti Horners-heilkennis. Birt med leyfi Dr. Frank Gaillard, Radiopegia. org. 


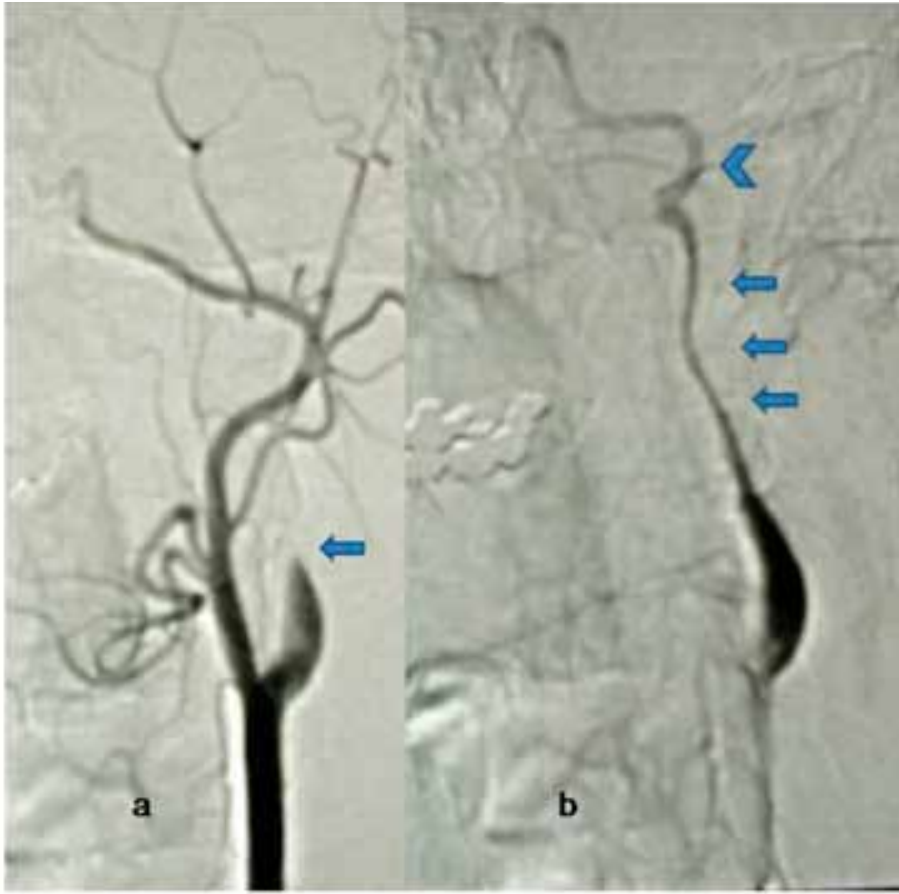

Mynd 4. Æðamynd (DSA) sýnir dæmigert útlit við flysjun í innri hálsslagæð. Fyrstu myndir (a) eftir inndælingu skuggaefnis gefa til kynna strýtulaga lokun (ör). Sein mynd (b), sýnir daufa fyllingu upp grannt holrúm innri hálsslagæðar (,string sign“, örvar). Æðin innan höfuðkúpu er merkt með örvaroddi.
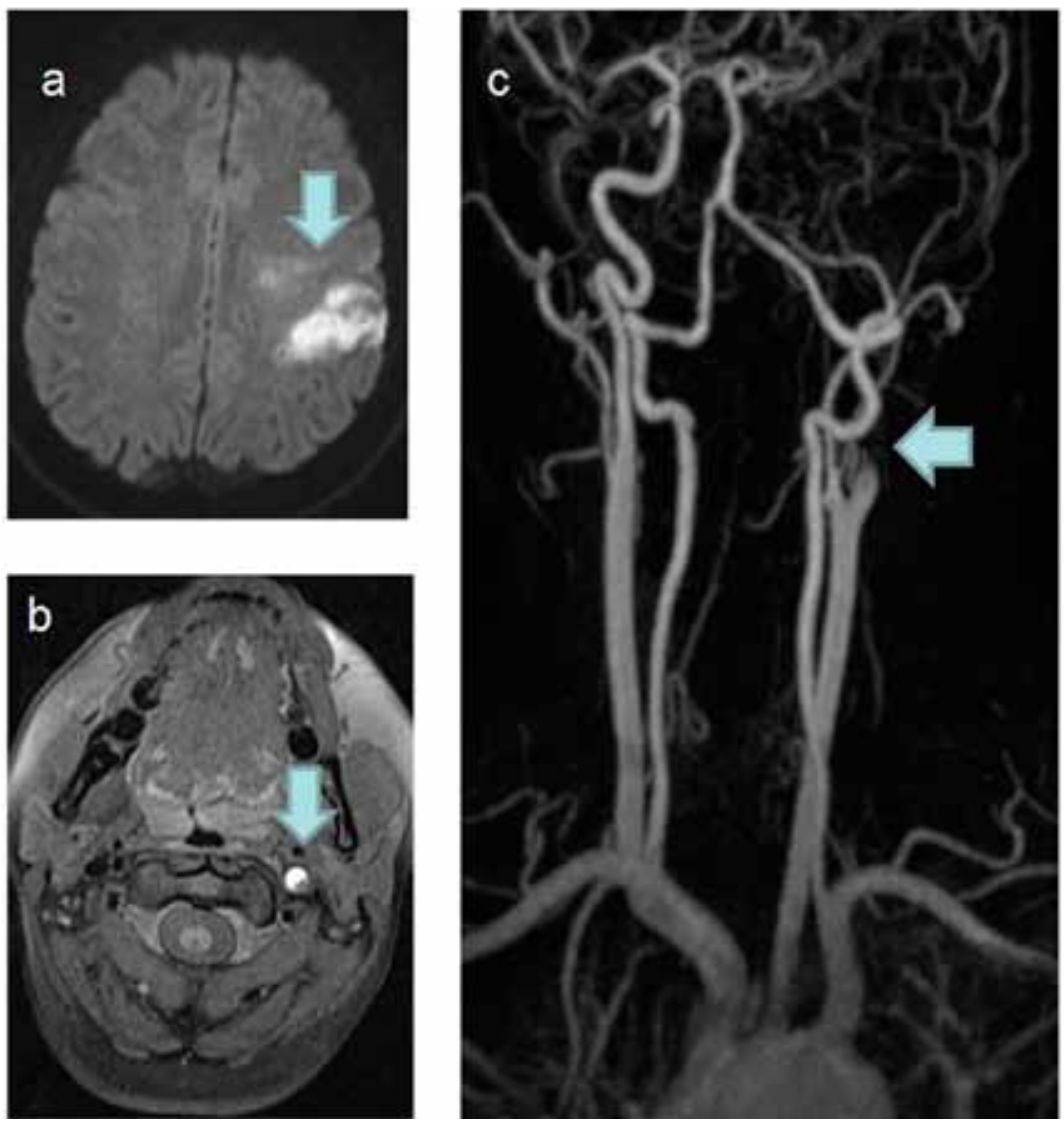

Mynd 5. Flæðisviktuð (DWI) segulómmynd (a) sýnir ferskt drep (ör) á næringarsvæði vinstri miðhjarnaslagæðar sem er afleiðing af flysjun í vinstri innri hálsslagæð. T1 viktuð mynd með fitumettunar púls (b) sýnir margúl í vegg innri hálsslagæðar (ör). Margúllinn sést sem sigðlaga segulskær rönd umhverfis hol æðarinnar. Enduruppbyggð segulómmynd i krónuskurđi (c) af hálsslagæðum eftir skuggaefnisgjöf i æð sýnir strýtulaga prengingu á vinstri innri hálsslagæð (ör) sem er dæmigert útlit fyrir flysjun á innri hálsæð. rúmi æðar, staðbundin víkkun á eiginlegu holrúmi æðar eða falskur gúll. Pær myndgreiningarannsóknir sem geta sýnt fram á eina eða fleiri pessara breytinga eru hefðbundin slagæðamyndataka, æðamyndataka með tölvusneiðmyndatæki(TS), æðamyndataka með segulómtæki (SÓ) og ómskoðun á hálsæðum.

Hefðbundin æðamyndataka getur sýnt ílanga, oft reglulega prengingu á holrúmi æðar, svokallað „,string sign“ og ef æðin er nær lokuð vegna flysjunar endar skuggaefnisfyllingin í strýtu eða keilu (mynd 4).

Ómskoðun kemur einkum að gagni við upphafsmat og frumgreiningu á flysjun í hálsslagæðum. Ómskoðun sýnir óeðlilegt flæði í innri hálsslagæð hjá um pað bil 90\% tilfella og í hryggslagæð hjá um pað bil $75 \%$ tilfella. ${ }^{40}$ Sértækast er pegar tvö æðaholrúm aðskilin með ómríkum æðapelsflipa greinast. Blæðing í æðarvegg getur sést sem ómríkt svæði umhverfis prengt holrúm slagæðar.

Æðaskoðun með segulómtæki er ekki síðri en hefðbundin æðamyndataka hvað varðar næmi og sértækni til greiningar flysjunar. ${ }^{34-36}$ Segulómun sýnir vel margúl í æðarvegg sem er meinkennandi fyrir flysjun (sjá mynd 5). ${ }^{37}$ Margúllinn sést vel á $\mathrm{T} 1$ viktuðum myndum sem teknar eru með endurteknum fitumettandi púls (fat suppression), en slík myndröð slær út myndmerki frá róteindum í fitu, sem pá gefur ekki frá sér myndmerki og er dökk á mynd. Margúllinn sést hins vegar sem segulskær rönd umhverfis segulsnautt holrúm æðarinnar. Rannsókn með skuggaefni sýnir einnig vel prengingu eða lokun á holrúmi æðar og falskt holrúm sem eru dæmigerðar afleiðingar flysjunar. Segulómrannsókn gefur auk pess glögga mynd af stærð og staðsetningu heiladreps sem er algeng afleiðing flysjunar. Greiningargeta segulómunar pegar flysjun hálsslagæðar á í hlut er pví bæði öflug og fjölbreytileg.

TS-æðaskoðun (mynd 6) er einnig góð rannsókn til að greina flysjun í hálsslagæðum. ${ }^{38}$ Niðurstaða nýlegrar rannsóknar mælir pó með pví að segulómrannsókn sé beitt fyrst tilgreiningar en síðan megi nota TS eða hefðbundna æðarannsókn til að svara ákveðnum viðbótarspurningum sem upp kunna að koma. ${ }^{38}$ Önnur nýleg rannsókn leggur greiningarhæfni TS og SÓ að jöfnu. ${ }^{39}$ Skuggaefnisupphleðsla í æðarvegg utan óreglulegs/prengds holrúms æðar, ásamt auknu heildarpvermáli æðar borið saman við sömu æð andstæðrar hliðar, er pað teikn sem talið er áreiðanlegast fyrir flysjun á tölvusneiðmyndarannsókn. TS getur einnig sýnt flipa frá innsta lagi par sem rofið verður, prengingu, lokun á æð og falskan gúlp. 
Hið gullna viðmið í greiningu á flysjun í hálsslagæð er oftast talið hefðbundin æðamyndataka. Pessa fullyrðingu verður pó að skoða í sögulegu samhengi. Ólíklegt er að framskyggn rannsókn verði gerð héðan af til að bera saman næmi og sértækni SÓ og TS annars vegar og hefðbundinna æðamynda hins vegar. Í dag er notkun SÓ og TS-æðarannsókna orðin mjög útbreidd og mun fleiri æðarannsóknir með TS og SÓ eru gerðar fyrr í sjúkdómsgangi hjá sjúklingum með blóðpurrðareinkenni. Pessar rannsóknir tilheyra peim bráđarannsóknum sem nú er gripið til hjá sjúklingum sem taldir eru hafa blóðpurrðareinkenni frá heila. Pessum rannsóknaraðferðum fylgir mun minna inngrip og minni áhætta borið saman við hefðbundna æðamyndatöku.

Myndgreining flysjunar í hálsslagæð er oft talsvert vandasöm og pví getur purft að nota fleiri en eina greiningartækni til staðfestingar eða útilokunar pegar klínískur grunur um flysjun vaknar. Rétt er að hafa í huga að hvort sem SÓ eða TS-æðaskoðun er notuð sem upphafsrannsókn gefa pessar greiningaraðferðir mismunandi upplýsingar og geta bætt hvor aðra upp. Dæmi um slíkt er pegar sýnt er fram á blæðingu í æðavegg með einfaldri segulómskoðun pegar aðeins hefur vaknað grunur um flysjun við TS-æðaskoðun. Á sama hátt getur TS-æðaskoðun bætt upp SÓ pegar flysjun leiðir til langrar prengingar á holrúmi æðar eða skilur eftir sig falskan gúlp. ${ }^{39}$ Aðgengi að TS er almennt betra og tæknin hefur tekið stórstígum framförum á undanförnum árum með tilkomu fjölsneiðatækja. Pví telja höfundar pessarar greinar eðlilegt að TS-æðarannsókn sé beitt sem fyrstu rannsókn við grun um flysjun í hálsslagæð.

Vegna talsverðrar jónandi geislunar við æðarannsókn með tölvusneiðmyndatæki er mælt með pví að myndrænt eftirlit með sjúklingum með hálsslagæðaflysjun, sem flestir eru undir fimmtugu, fari fram með segulómun eða ómskoðun.

\section{Meðferð}

Mikilvægt er að geta pess að flysjun er ekki frábending gagnvart bráða-segaleysandi meðferð við heilablóðpurrð svo lengi sem önnur skilyrði eru uppfyllt. ${ }^{46,47}$

Sennilegt pykir að sárið á æðaveggnum og hið iðukennda blóðflæði sem af flysjuninni hlýst valdi segamyndun- og reki með líkum hætti og gerist við gáttatif. ${ }^{41}$ Tvær rannsóknir með samanlagt 181 sjúklingi hafa stutt pá tilgátu að blóðpurrð eftir flysjun stafi oftast af segareki. ${ }^{42,}{ }^{43}$ Út frá pessum

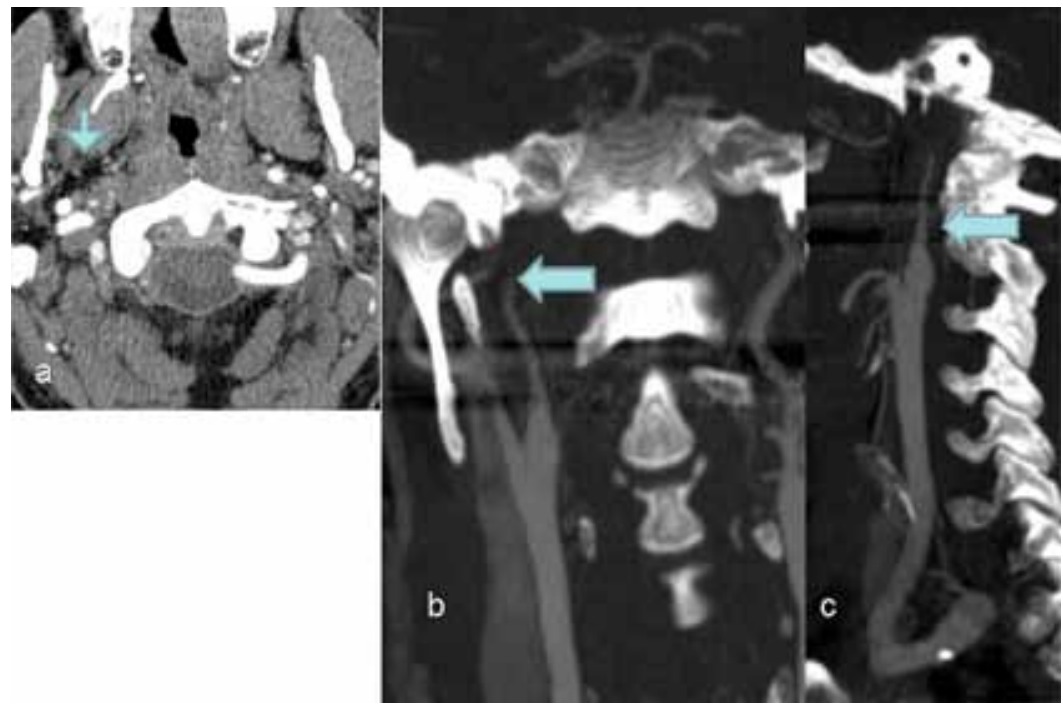

hugmyndum hafa menn ályktað að blóðpynning sé áhrifameiri en blóðflöguhemjandi meðferð. Enda pótt ekki séu til neinar slembiraðaðar rannsóknir á meðferð flysjunar mæla flestir höfundar með heparín-innrennsli í æð eða lágmólekúlar heparíni undir húo í eina til tvær vikur í upphafi meðferðar. Síðan er mælt með warfarín-töflumeðferð um munn með pað að markmiði að halda INR milli 2,0-3,0. Peirri meðferð er beitt í prjá til sex mánuði og pá er myndrannsókn endurtekin. Ef æðin er talin hafa tekið á sig nokkurn veginn upprunalegt form er blóðpynningu hætt. Ef undirliggjandi sjúkdómur eins og fibromuscular dysplasia er til staðar eða ef æðin er áfram lokuð, eða holrúmið mjög pröngt, mæla flestir höfundar með acetýlsalisílsýru 75-100 mg á dag um ótiltekinn tíma. Aðrir höfundar telja nægjanlegt að meðhöndla með acetýlsalisílsýru frá upphafi, ekki síst ef flysjunin veldur óverulegum breytingum á holrúmi æðar. Ofangreindar ráðleggingar eru alfarið byggðar á klínískri reynslu. ${ }^{1}$

Við endurtekin blóðpurrðareinkenni prátt fyrir hefðbundna lyfjameðferð getur útvíkkandi viðgerð á æðaprengslum og ísetning stoðnets (stents) komið til greina (sjá mynd 7). ${ }^{44}$ Sérstaklega hefur slík meðferð verið reynd hjá sjúklingum með vaxandi blóðpurrðareinkenni prátt fyrir lyfjameðferð. ${ }^{45}$ Pegar viðvarandi og sveiflukennd blóðpurrðareinkenni eru til staðar og æðin er mikið prengd vegna flysjunar má reyna rúmlegu í láréttri stöðu, jafnvel með lægra undir höfði, pangað til einkenni eru orðin stöðug og innankúpublóðflæðið hefur batnað. Ástandið er pá metið á grundvelli klínískra einkenna og með aðstoð ómskoðunar og segulóm- og tölvusneiðmyndatækni. ${ }^{32}$
Mynd 6. TS-æðaskoðun með skuggaefni sýnir enga fyllingu í hæori innri hálsslagæð samkvæmt pversneið úr æðaskoðun (a, ör) en enduruppbyggðar myndir ípversneiðum (b) og í langsumplönum (c) sýna strýtulaga prengingu i æðinni og par fyrir ofan granna fyllingu (, „string sign") (ör) Útlitið er dæmigert fyrir flysjun. 

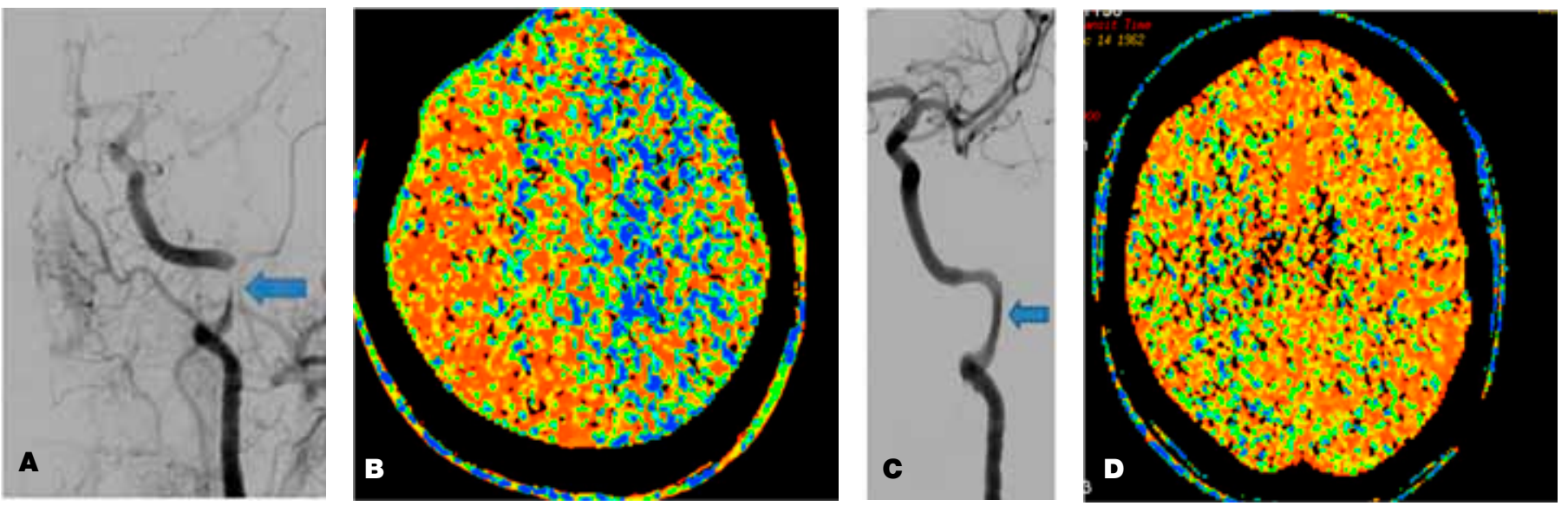

\section{Horfur}

Mynd 7. Dæmi um einstakling sem hafði einkenni um blóðpurrð i vinstra heilahveli vegna flysjunar í innri hálsslagæð. Mynd (a), hefðbundin æðamyndataka sýnir flysjunina (ör). TS heilavefsgegnumflæðismynd (mean transit time) (b), sýnir minna gegnumflæði (cerebral perfusion) í vinstra heilahveli (blár litur). Á mynd (c) er vinstri innri

hálsslagæð opin eftir isetningu stoðnets, (ör). Á mynd (d) má sjá eđilegt heilavefsgegnumflæði (mean transit time) í vinstra heilahveli eftir ísetningu stoðnetsins.
Horfur sjúklings ráđast af alvarleika heilablóðpurrðar ef hún hefur átt sér stað. Flysjun í innri hálsslagæð virðist hafa heldur verri afleiðingar í för með sér en flysjun í hryggslagæð. Dánartíðnin í bráđaveikindunum er mjög lág (innan við 2\%). ${ }^{5}$ Stórt heiladrep, oftast á næringarsvæði miðhjarnaslagæðar, er algengasta dánarorsökin. Langtímahorfur sjúklinga með flysjun virðast almennt góðar. Meirihluti sjúklinga (80-85\%) nær sér að fullu eða býr við væga fötlun. ${ }^{5}$

Tíðni endurtekinna heilaáfalla vegna nýrrar flysjunar er mjög lág, líklega undir 1\% á ári fyrstu árin eftir upphafsveikindin. Hættan er talin mest fyrstu mánuðina. 5, 18, 48, 49 Áhættupættir fyrir endurtekinni flysjun eru illa skilgreindir en fjölskyldusaga um flysjun getur aukið líkur á endurkomu sjúkdómsins. ${ }^{50}$ Í peim tilvikum er líklegt að áhættupáttur eins og bandvefssjúkdómur liggi til grundvallar.

Pegar sjúklingum með flysjun er fylgt eftir með endurteknum myndrannsóknum sést að innan nokkurra vikna eða mánaða hafa 60-80\% prenginga gengið til baka og priðjungur lokaðra æða opnast aftur. ${ }^{5}$

\section{Lokaorð}

Með bættum greiningaraðferðum og aukinni vitneskju er hálsslagæðarflysjun mikilvæg mismunagreining pegar leitað er orsakar heilablóðfalls, sér í lagi hjá ungum og miðaldra sjúklingum. Hafa ber í huga að flysjun kemur einnig fyrir hjá eldra fólki. Með pví að greina og meðhöndla flysjun snemma er að öllum líkindum hægt að draga úr hættu á heiladrepi og varanlegri fötlun. Mikilvægt er að framkvæma myndrannsókn hjá grunuðum tilfellum á fyrsta sólarhring. Almennt er heparín-innrennsli eða lágmólekúlarheparín $\left(\operatorname{Klexan}^{\circledR}\right.$, Fragmin $\left.^{\circledR}\right)$ notað í upphafi og svo warfarín í prjá til sex mánuði.
Pá er myndrannsókn endurtekin og ef æðin er talin hafa tekið á sig nokkurn veginn eðlilegt form er frekari meðferð oftast talin ópörf. Ef áhættupættir, eins og bandvefssjúkdómar, eru taldir liggja til grundvallar eða ef æðin er áfram lokuð eða holrúmið mjög pröngt, mæla margir höfundar með acetýlsalisílsýru 75-100 mg á dag um ótiltekinn tíma.

\section{Heimildir}

1. Schievink WI. Spontaneous dissection of the carotid and vertebral arteries. N Engl J Med 2001; 12: 898-906.

2. Kristensen B, Malm J, Carlberg B, et al. Epidemiology and etiology of ischemic stroke in young adults aged 18 to 44 years in northern Sweden. Stroke 1997; 28: 1702-9.

3. Schievink WI, Mokri B, Whisnant JP. Internal carotid artery dissection in a community. Rochester, Minnesota, 1987-92. Stroke 1993; 24 : $1678-80$.

4. Giroud M, Fayolle H, André N, et al. Incidence of internal carotid artery dissection in the community of Dijon. J Neurol Neurosurg Psychiatry 1995; 57: 1443.

5. Metso TM, Metso AJ, Salonen O, et al. Adult cervicocerebral artery dissection: a single-center study of 301 Finnish patients. Eur J Neurol 2009; 16: 656-61.

6. Mokri B, Sundt TM Jr, Houser OW, Piepgras DG. Spontaneous dissection of the cervical internal carotid artery. Ann Neurol 1986; 19:126-38

7. Schievink WI, Michels VV, Piepgras DG. Neurovascular manifestations of heritable connective tissue disorders: a review. Stroke 1994; 25: 889-903.

8. Schievink WI, Björnsson J, Piepgras DG. Coexistence of fibromuscular dysplasia and cystic medial necrosis in a patient with Marfan s syndrome and bilateral carotid artery dissections. Stroke 1994; 25; 2492-6.

9. Grond-Ginsbach C, Weber R, Haas J, et al. Mutations in the COL5A1 coding sequences are not common in patients with spontaneous cervical artery dissections. Stroke 1999; 30: 1887-90.

10. Brandt T, Hausser I, Orberk E, et al. Ultrastructural connective tissue abnormalities in patients with spontaneous cervico-cerebral artery dissections. Ann Neurol 1998; 44: 281-5.

11. Brandt T, Grond-Ginsbach C. Spontaneous cervical artery dissection: from risk factors toward pathogenesis. Stroke 2002; 33: 657-8.

11. Pezzini A, Del Zotto E, Archetti S, et al. Plasma homocysteine concentration, C677T MTHFR genotype, and 844ins68bp CBS genotype in young adults with spontaneous cervical artery dissection and artherothrombotic stroke. Stroke 2002; 33: 664-9.

12. Pezzini A, Del Zotto E, Padovani A. Hyperhomocysteinemia: a potential risk factor for cervical artery dissection following chiropractic manipulation of the cervical spine. J Neurol 2002; 10: 1401-3

13. Caso V, Gallai V. Why should mild hyperhomocysteinemia be responsible for CAD? Stroke 2003; 34: e209. 
14. D Anglejan-Chatillon J, Ribeiro V, Mas JL, Youl BD, Bousser MG. Migraine-a risk factor for dissection of cervical arteries. Headache 1989; 29: 560-1.

15. Tzourio C, Benslamia L, Guillon B, et al. Migraine and the risk of cervical artery dissection: a case-control study. Neurology 2002; 59: 435-7.

16. Tzourio C, El Amrani M, Robert L, Alperovitch A. Serum elastase activity is elevated in migraine. Ann Neurol 2000; 47: 648-51.

17. Schievink WI, Mokri B, O'Fallon WM. Recurrent spontaneous cervical- artery dissection. N Engl J Med 1994; 330: 393-7.

18. Fisher CM, Ojemann RG, Roberson GH. Spontaneous dissection of cervico-cerebral arteries. Can J Neurol Sci 1978; 5: 9-19.

19. Mokri B, Sundt TM Jr, Houser OW. Spontaneous internal carotid dissection, hemicrania, and Horner's syndrome. Arch Neurol 1979; 36: 677-80.

20. Hart RG, Easton JD. Dissections of cervical and cerebral arteries. Neurol Clin 1983; 1: 155-82.

21. Mokri B. Traumatic and spontaneous extracranial internal carotid artery dissections. J Neurol 1990; 237: 356-61.

22. Hufnagel A, Hammers A, Schonle P-W, Bohm K-D, Leonhardt G. Stroke following chiropractic manipulation of the cervical spine. J Neurol 1999; 246: 683-8.

23. Malm J, Olsson T, Fagerlund M. Cervikal manipulation kan ge hjärninfarkt. Läkartidningen 1990; 46: 3877-79.

24. Rothwell DM, Bondy SI, Williams JI. Chiropractic manipulation and stroke: a population-based case-control study. Stroke 2001; 32: 1054-60.

25. Caplan LR, Zarins CK, Hemmati M. Spontaneous dissection of the extracranial vertebral arteries. Stroke 1985; 16: 1030-8.

26. Guillon B, Berthet $\mathrm{K}$, Benslamia L, Bertrand M, Bousser MG Tzourio C. Infection and the risk of spontaneous cervical artery dissection: a case-control study. Stroke 2003; 34: e79.

27. Grau AJ, Brandt T, Buggle F, et al. Association of cervical artery dissection with recent infection. Arch Neurol 1999; 56 851-6.

28. Schievink WI, Wijdics EFM, Kuiper JD. Seasonal pattern of spontaneous cervical artery dissection. J Neurosurg 1998; 89: 101-3.

29. Biousse V, D'Anglejan-Chatillon J, Massiou H, Bousser M-G. Head pain in non-traumatic carotid artery dissection: a series of 65 patients. Cephalalgia 1994; 14: 33-6.

30. Silbert PL, Mokri B, Schievink WI. Headache and neck pain in spontaneous internal carotid and vertebral artery dissections. Neurology 1995; 45: 1517-22.

31. Biousse V, D'Anglejan-Chatillon J, Massiou H, Bousser MG. Time course of symptoms in extracranial carotid artery dissections. A series of 80 patients. Stroke 1995; 26: 235-9.

32. Mokri B, Houser OW, Sandok BA, Piepgras DG. Spontaneous dissections of the vertebral arteries. Neurology 1998; 38: 880-

33. Djouhri H, Guillon B, Brunereau L, et al. MR angiography for the long-term follow-up of dissecting aneurysms of the extracranial internal carotid artery. Am J Roentgenol 2000; 174: $1137-40$.
34. Kasner SE, Hankins LL, Bratina P, Morgenstern LB Magnetic resonance angiography demonstrates vascular healing of carotid ad vertebral artery dissections. Stroke 1997; 28: 1993-7.

35. Kirsch E, Kaim A, Engelter S, et al. MR angiography in internal carotid artery dissection: improvement of diagnosis by selective demonstration of the intramural haematoma. Neuroradiology 1998; 40: 704-9.

36. Auer A, Felber S, Schmidauer C, Waldenberger P, Aichner F. Magnetic resonance angiographic and clinical features of extracranial vertebral artery dissection. J Neurol Neurosurg Psychiatry 1998; 64: 474-81.

37. Caplan LR. Dissections of brain-supplying arteries. Nat Clin Pract Neurol 2008; 4: 34-42.

38. Vertinsky AT, Schwartz NE, Fischbein NJ, Rosenberg J, Albers GW, Zaharchuk G. Comparison of multidetector CT angiography and MR imaging of cervical artery dissection. Am J Neuroradiol 2008; 29: 1753- 60.

39. Sturzenegger M, Mattle HP, Rivoir A, Rihs F, Schmid C. Ultrasound findings in spontaneous extracranial vertebral artery dissection. Stroke 1993; 24: 1910-21.

40. Norris JW, Brandt T. Management of cervical arterial dissection. Int J Stroke 2006; 1: 59-64.

41. Benninger DH, Georgiadis D, Kremer C, Studer A, Nedeltchev K, Baumgartner RW. Mechanism of ischemic infarct in spontaneous carotid dissection. Stroke 2004; 35: $482-5$.

42. Lucas C, Moulin T, Deplanque D, Tatu L, Chavot D. Stroke patterns of internal carotid artery dissection in 40 patients. Stroke 1998; 29: 2646-8.

43. Malek AM, Higashida RT, Phatouros CC, et al. Endovascular management of extracranial carotid artery dissection achieved using stent angioplasty. AJNR Am J Neuroradiol 2000; 21: 1280-92.

44. Cohen JE, Leker RR, Gotkine M, Gomori M, Ben-Hur T. Emergent stenting to treat patients with carotid artery dissection: clinically and radiologically directed therapeutic decision making. Stroke 2003; 34: 254-7.

45. Arnold $M$, Nedeltchev $K$, Sturzenegger $M$, et al. Thrombolysis in patients with acute stroke caused by cervical artery dissection. Arch Neurol 2002; 59: 549-53.

46. Georgiadis D, Lanczik O, Schwab S, et al. IV thrombolysis in patients with acute stroke due to spontaneous carotid dissection. Neurology 2005; 64: 1612-4.

47. Touzé E, Gauvrit JY, Moulin T, Meder JF, Bracard S, Mas JL. Multicenter Survey on Natural History of Cervical Artery Dissection. Risk of stroke and recurrent dissection after a cervical artery dissection: a multicenter study. Neurology 2003; 61: 1347-51

48. Schievink WI, Wijdicks EFM, Michels VV, Vockley J, Godfrey M. Heritable connective tissue disorders in cervical artery dissections: a prospective study. Neurology 1998; 50: 1166-9.

49. Schievink WI, Mokri B, Piepgras DG, Kuiper JD. Recurrent spontaneous arterial dissections. Risk in familial versus nonfamilial disease. Stroke 1996; 27: 622-4.

\section{Cervical artery dissection - review}

In recent years carotid and vertebral artery dissections have been diagnosed more frequently, probably because new imaging techniques are more reliable and they are certainly less invasive. The cause of cervical artery dissections is largely unexplained but probably involves a combination of genetic and environmental factors such as trauma or infection.

Most authors recommend intravenous heparin or low molecular weight heparin followed by oral warfarin to maintain INR between 2-3 for 3-6 months. If the artery has healed after 3-6 months of anti-coagulation all treatment can be stopped but if there is a remaining stenosis the patient can be put on aspirin $75-100 \mathrm{mg}$ a day. The longterm prognosis of cervical artery dissection is favourable in the majority of patients. New dissections are uncommon.

Sveinsson OA, Kjartansson O,Valdimarsson EM 